\title{
Evolutionary divergence between sympatric species of southern African Hakes, Merluccius capensis and M. paradoxus. II. Restriction enzyme analysis of mitochondrial DNA
}

Inga I. Becker,

W. Stewart Grant*, Ralph Kirby and

Frank T. Robb
Department of Microbiology, University of Cape Town, Rondebosch 7700, South Africa.

We used 11 restriction endonucleases to measure nucleotide sequence variation in mitochondrial DNA (mtDNA) within and between two species of hake from the coastal waters of South Africa. A total of 14 different composite genotypes were observed among 26 individuals of Merluccius capensis, but only 6 composite genotypes were observed for 24 individuals of $M$. paradoxus. A parsimony network connecting the composite genotypes for these species did not correspond with the geographies of either set of samples. In $M$. capensis, the restriction patterns of three enzymes (Ava I, $X b a$ I, Xho I) and the network of composite genotypes indicate that an addition of about 400 nucleotides in length and a deletion of 200 nucleotides have occurred in pathways leading from the most common genotype. The amount of nucleotide site polymorphism for $M$. capensis was 0.022 and was significantly greater than the level of polymorphism in $M$. paradoxus, which was 0.009 . These results suggest that $M$. paradoxus may have experienced a population bottleneck in the past. The amount of sequence divergence between these species was 11.6 per cent $( \pm 0.036)$ and is typical for well differentiated species. Using the assumptions of the molecular clock, this represents a divergence time of $5.8( \pm 1.8)$ million years.

\section{INTRODUCTION}

The analysis of sequence variation in mitochondrial DNA (mtDNA) with restriction endonucleases has proved to be a useful complement to other molecular and morphological methods of studying natural populations. Mitochondrial DNA nucleotide sequences appear to evolve about ten times faster than those in single copy nuclear genes (Brown et al., 1979) and, hence, may be capable of resolving recent population genetic events (e.g., Bermingham and Avise, 1986). Mitochondrial DNA also differs from nuclear DNA in that it is inherited through the female parent (Giles et al., 1980) and is therefore useful for studying maternal lineages and introgressive hybridisation (e.g., Lamb and Avise, 1986). Another application of

* Present address: Department of Genetics, University of the Witwatersrand, Johannesburg 2050, South Africa. this method is the measurement of divergence between species and the use of these data to make evolutionary and taxonomic inferences.

In this study we used resriction-enzyme fragment analysis of mtDNA to study two sympatric species of hake, Merluccius capensis and $M$. paradoxus. The distributions of these fishes are associated with the cold temperate Benguela Upwelling System and overlap over portions of their geographic and bathymetric ranges (see Grant et al., $1988 b$ ). A previous study of geographic variation using allozymes showed that there were two weakly differentiated regional populations of $M$. capensis, but no geographic differentiation was detected for M. paradoxus (Grant et al., 1988a). The samples used in the present study were collected from the southern stocks for both species. Although these species are morphologically very similar, allozyme data suggest that they have from one another to a considerable extent (Grant et al., 1988b). 
Our chief goals were to search for possible genetic differences between regional populations within the two species and to measure the amount of genetic divergence between species. Although freshwater fishes show a large amount of mtDNA sequence variation which coincides with geographic populations (Bermingham et al., 1986), there appears to be much less geographic subdivision among marine fishes (Graves et al., 1984; Avise et al., 1986). There have been too few studies of mtDNA in marine fishes, however, to know if this is generally true.

\section{MATERIALS AND METHODS}

Whole fish were collected by commercial trawlers or by the R.S. Africana (table 1, fig. 1) and placed immediately on ice. Mitochondria were isolated from liver or mature oocytes stored for less than $24 \mathrm{hr}$ in most cases, but good yields were obtained from samples stored on ice for as long as one week. We chose mature ovaries because they contain little connective tissue, the glycogen content is low and the ratio of mtDNA to nuclear DNA is on the order of $300: 1 \mathrm{w} / \mathrm{w}$ (Chapman and Powers, 1984). During the non-spawning season when oocytes were not available, we used liver as a source of mitochondrial DNA. Tissues were homogenised with an Ultra-Turrox homogeniser (type TP 18/10) for 3 to 5 seconds at top speed. Mitochondria were then extracted by differential centrifugation after the method of Chapman and Powers (1984).

Portions of the extracted mtDNA from each individual were digested with one 5-base recognition site restriction endonuclease, Ava I and ten 6-base restriction endonucleases, $B a m \mathrm{HI}, B g l \mathrm{I}$, Eco RI, Hind III, Kpn I, Pst I, Pvu II, Sac I, Xba I

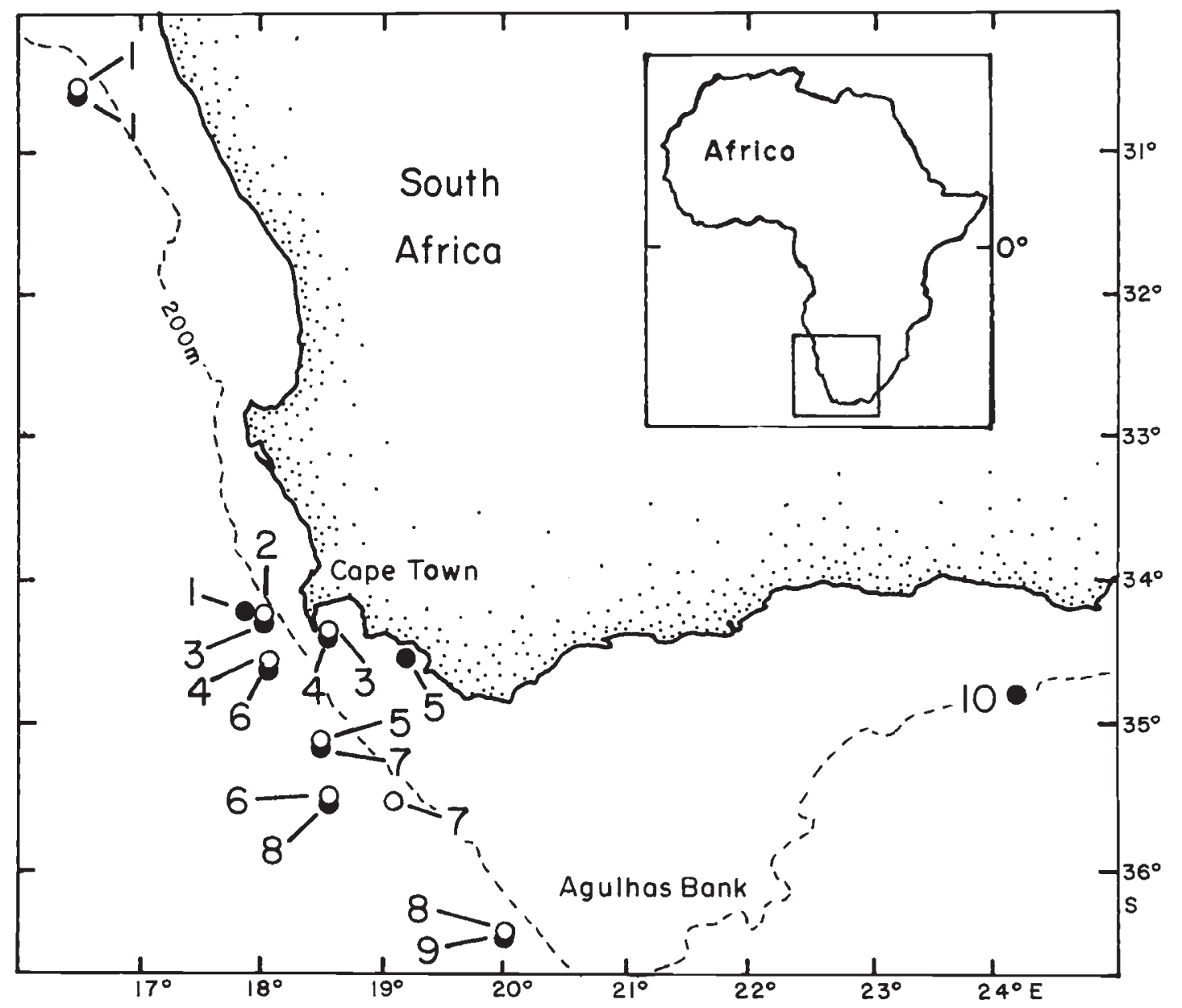

Figure 1 Locations of hake samples used for mtDNA analysis. Closed circles represent samples of Merluccius capensis and open circles represent samples of $M$. paradoxus. 
Table 1 Locations and dates of samples

\begin{tabular}{|c|c|c|c|c|c|}
\hline \multirow[b]{2}{*}{ Sample number } & \multicolumn{2}{|c|}{ Location } & \multirow[b]{2}{*}{ Date collected } & \multirow[b]{2}{*}{ Depth (m) } & \multirow[b]{2}{*}{ Sample size } \\
\hline & S. lat. & E. long. & & & \\
\hline \multicolumn{6}{|c|}{ Merluccius capensis } \\
\hline 1 & $30^{\circ} 30^{\prime}$ & $16^{\circ} 30^{\prime}$ & Jan. 1986 & 249 & 3 \\
\hline 2 & $34^{\circ} 10^{\prime}$ & $17^{\circ} 50^{\prime}$ & Dec. 1985 & 200 & 4 \\
\hline 3 & $34^{\circ} 10^{\prime}$ & $17^{\circ} 55^{\prime}$ & Dec. 1985 & 180 & 2 \\
\hline 4 & $34^{\circ} 15^{\prime}$ & $18^{\circ} 35^{\prime}$ & Nov. 1985 & & 2 \\
\hline 5 & $34^{\circ} 20^{\prime}$ & $19^{\circ} 15^{\prime}$ & Sep. 1985 & 200 & 2 \\
\hline 6 & $34^{\circ} 25^{\prime}$ & $18^{\circ} 02^{\prime}$ & Dec. 1985 & 350 & 1 \\
\hline 7 & $35^{\circ} 01^{\prime}$ & $18^{\circ} 35^{\prime}$ & Dec. 1985 & 237 & 5 \\
\hline 8 & $35^{\circ} 25^{\prime}$ & $18^{\circ} 45^{\prime}$ & Nov. 1985 & 425 & 1 \\
\hline 9 & $36^{\circ} 21^{\prime}$ & $20^{\circ} 03^{\prime}$ & Nov. 1985 & 284 & 1 \\
\hline 10 & $34^{\circ} 45^{\prime}$ & $24^{\circ} 10^{\prime}$ & Jan. 1986 & 147 & 5 \\
\hline \multicolumn{6}{|c|}{ Merluccius paradoxus } \\
\hline 1 & $30^{\circ} 30^{\prime}$ & $16^{\circ} 30^{\prime}$ & Jan. 1986 & 249 & 4 \\
\hline 2 & $34^{\circ} 10^{\prime}$ & $17^{\circ} 55^{\prime}$ & Dec. 1985 & 180 & 2 \\
\hline 3 & $34^{\circ} 15^{\prime}$ & $18^{\circ} 35^{\prime}$ & Nov. 1985 & & 2 \\
\hline 4 & $34^{\circ} 25^{\prime}$ & $18^{\circ} 02^{\prime}$ & Dec. 1985 & 350 & 4 \\
\hline 5 & $35^{\circ} 01^{\prime}$ & $18^{\circ} 35^{\prime}$ & Dec. 1985 & 237 & 2 \\
\hline 6 & $35^{\circ} 25^{\prime}$ & $18^{\circ} 45^{\prime}$ & Nov. 1985 & & 1 \\
\hline 7 & $35^{\circ} 30^{\prime}$ & $19^{\circ} 05^{\prime}$ & Nov. 1985 & 425 & 6 \\
\hline 8 & $36^{\circ} 21^{\prime}$ & $20^{\circ} 03^{\prime}$ & Nov. 1985 & 284 & 3 \\
\hline
\end{tabular}

and Xho I, which were supplied by Amersham Ltd., Anglian Biotechnology Ltd. and Boeringer Mannheim Ltd. Digestion buffers and times followed manufacturer recommendations. DNAsefree RNAse $(4 \mu \mathrm{g} / \mathrm{ml})$ was added to each digestion to reduce the amount of low molecular weight RNA in the extract. Endlabelling of digested fragments with ${ }^{32} \mathrm{P}$ followed Maniatis et al. (1982). DNA fragments were separated by electrophoresis in 0.7 to 1.0 per cent agarose gels as needed for the resolution of differently sized fragment. After electrophoresis gels were dried with a vacuum gel dryer, and autoradiography followed Maniatis et al. (1982). As an alternative to endlabelling, ethidium bromide $(0.5 \mu \mathrm{g} / \mathrm{ml})$ was added to gels before electrophoresis and subsequently photographed on a $254 \mathrm{~nm} \mathrm{UV} \mathrm{transluminator} \mathrm{with} \mathrm{a}$ Polaroid camera $(\mathrm{Cu} 5)$ and a Kodak $23 \mathrm{~A}$ orange filter. Lambda phage DNA, digested with Hind III or a mixture of Hind III and Eco RI, was run on each gel and used to estimate the sizes of the mtDNA fragments. Fragments with similar mobilities were electrophoresed side by side on the same gel to determine homology. We assumed that fragments with the same mobilities had identical nucleotide sequences.

\section{RESULTS}

Endonuclease digestion patterns of the mtDNAs from the two species of hake are presented in fig. 2 .
The following conventions were used to label the various fragment genotypes. The most common genotype in $M$. capensis was designated by the letter "A", and variant genotypes as well as genotypes in $M$. paradoxus by "B", "C", " $D$ ", etc. We attempted to identify mutational transitions from one genotype to another by examination of the sizes of the fragments. Genotypes differing by a single mutation were designated by an arrow where the direction of the arrow indicated a loss of a restriction enzyme recognition site. Direction in this sense does not imply evolutionary direction. Loss of a restriction site leads to the joining of two small fragments to create a larger fragment.

For example, the genotype $\mathrm{A}$ of $\mathrm{Bg} \mathrm{I} \mathrm{I}$ appears to be related to genotype $\mathrm{B}$ by the loss of a restriction site between fragments 1.4 and $1.2 \mathrm{~kb}$ in length to create a fragment $2.6 \mathrm{~kb}$ in length. For Sac I genotype $\mathrm{B}$ is related to genotype $\mathrm{A}$ by a gain of a restriction site producing a $3.70 \mathrm{~kb}$ fragment and an unobserved fragment of about 80 base pairs. Genotypes D and E of Sac I are related to genotype $F$ by two different restriction site gains. The genotypes of $X b a$ I and $X$ ho I, are more difficult to interpret. The same number of fragments appear for each of these genotypes in $M$. capensis. For $X b a$ I three fragments remained constant while a fourth fragment varied from 6.9 to $7.5 \mathrm{~kb}$ in length. For Xho I, one fragment remained constant while a second varied from 4.5 to $5 \cdot 1 \mathrm{~kb}$ in three genotypes. No fragments smaller than $0.6 \mathrm{~kb}$ were detected by endlabelling with ${ }^{32} \mathrm{P}$ for these en- 

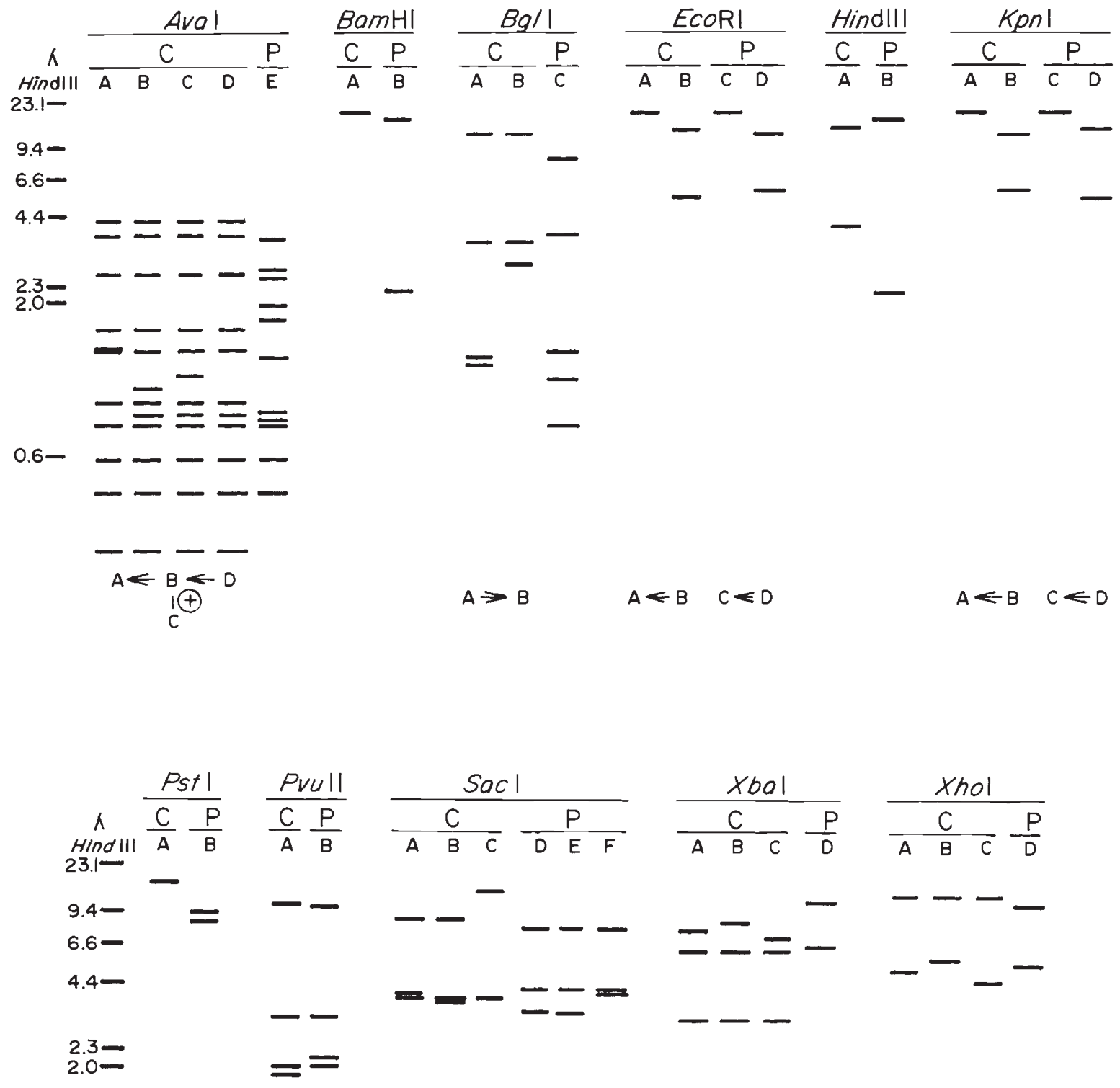

$0.6-$

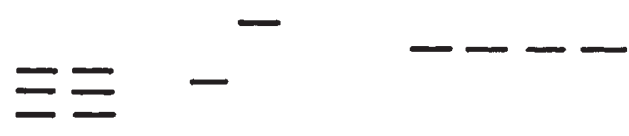

$$
A \leftarrow B \quad D \rightarrow F \leftarrow E \quad B \stackrel{\oplus}{\oplus} \stackrel{\Theta}{=} \quad \stackrel{\oplus}{A} \stackrel{\Theta}{-}
$$

Figure 2 Diagrammatic representations of endonuclease restriction digests of hake mtDNA. C stands for Merluccius capensis and $\mathrm{P}$ for $M$. paradoxus. Also shown are networks of relationship where arrows indicate the direction of a restriction site loss (but not necessarily the direction of evolution). Base paid additions are indicated by + and deletions by - 
zymes. These transitions are then best explained by an insertion of 400 base pairs and a deletion of 200 base pairs from genotype A. Genotype C of Ava I had the same number of bands as genotype $\mathrm{B}$, except that one fragment was about 400 base pairs iarger. This genotype also corresponds with the genotypes of $X b a \mathrm{I}$ and $X h o \mathrm{I}$ have the 400 base pair insert.

The data may be considered as a whole by combining individual genotypes into composite genotypes. A total of 14 composite genotypes were observed for $M$. capensis (table 2). We found three most-parsimonious networks connecting genotypes with a minimum of 22 mutation steps, an insertion and a deletion (fig. 3). In fig. 3, a hatch mark across a link between two genotypes indicates two or more mutations for a single restriction site. For example, the composite genotype AAAAAAAAAAA (1) is related to AAABAAAAAAA (2) by the appearance of a restriction site for Eco RI. Similarly, genotypes 2 and 5 differ for one restriction enzyme where at least 2 mutations are required to explain their differences. Genotype 6 was also related to genotype 2 by at least two or more steps, and genotype 11 to genotype 8 by at least two steps. An insertion is apparent between genotypes 1 and 7 and a deletion between genotypes 1 and 12 .
Genotypes 7-11, thus, contain a $0.4 \mathrm{~kb}$ insertion, and genotypes $12-14$ have a $0 \cdot 2 \mathrm{~kb}$ deletion.

It was not possible to match the network of composite genotypes with sample locations in any meaningful way. For $M$. capensis, two of the most common composite genotypes appeared in 6 individuals each which were distributed over the entire range of our sampling. The remaining genotypes appeared in individuals collected at various locations over the sampling area. For $M$. paradoxus, six composite genotypes were observed and the most common composite genotype occurred in 12 individuals that were also widely distributed. Five less-frequent genotypes occurred at various locations. In the parsimony network, genotype 6 was related to genotype 1 by a single step and genotype 5 to genotype 4 by at least two steps.

We estimated the proportion of the polymorphic nucleotide sites using equations (6) in Engels (1981) and (2) in Hudson (1982) with the standard error according to equation (11) in Hudson (1982). To estimate the amount of sequence divergence between species we first estimated the number of restriction fragments shared between different composite genotypes $(F)$ by

$$
F=2 n_{x y} /\left(n_{x}+n_{y}\right)
$$

Table 2 Composite genotypes of $M$. capensis and $M$. paradoxus. Each letter in the composite genotype presents the restriction-enzyme fragment genotypes of Ava I, Bam HI, Bgl I, Eco RI, Hind III, Kpn I, Pst I, Pvu II, Sac I, Xba I, and Xho I, respectively

\begin{tabular}{|c|c|c|c|}
\hline $\begin{array}{l}\text { Clonal } \\
\text { designation }\end{array}$ & $\begin{array}{l}\text { Composite } \\
\text { genotype }\end{array}$ & $\begin{array}{l}\text { Number of } \\
\text { individuals }\end{array}$ & Location \\
\hline \multicolumn{4}{|c|}{ Merluccius capensis } \\
\hline 1 & AAAAAAAAAAA & 6 & $1,2,5,7,10$ \\
\hline 2 & AAABAAAAAAA & 6 & $1,2,10$ \\
\hline 3 & AAAAABAAAAA & 1 & 7 \\
\hline 4 & AAABAAAACAA & 1 & 1 \\
\hline 5 & DAABAAAAAAA & 2 & 2,3 \\
\hline 6 & BAABABAABAA & 1 & 4 \\
\hline 7 & AAAAAAAAABB & 1 & 5 \\
\hline 8 & AAABAAAAABB & 2 & 9,10 \\
\hline 9 & AABBAAAAABB & 1 & 6 \\
\hline 10 & CAAAAAAABBB & 1 & 4 \\
\hline 11 & AAABABAABBB & 1 & 7 \\
\hline 12 & AAAAAAAAACC & 1 & 7 \\
\hline 13 & AAABABAAACC & 1 & 3 \\
\hline 14 & AAABAAAABCC & 1 & 8 \\
\hline \multicolumn{4}{|c|}{ Merluccius paradoxus } \\
\hline 1 & EBCABABBDDD & 13 & $1,2,4,5,7,8$ \\
\hline 2 & EBCABABBEDD & 1 & 1 \\
\hline 3 & EBCABABBFDD & 2 & 1,5 \\
\hline 4 & EBCABCBBFDD & 1 & 3 \\
\hline 5 & EBCCBCBBDDD & 3 & 3,7 \\
\hline 6 & EBCCBABBDDD & 4 & 6,7 \\
\hline
\end{tabular}


M. capensis

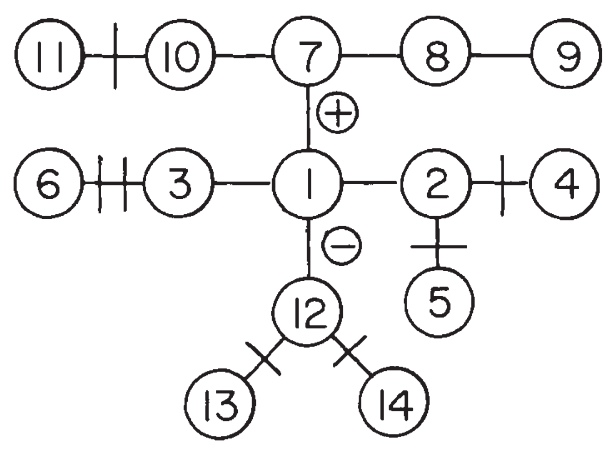

M. paradoxus

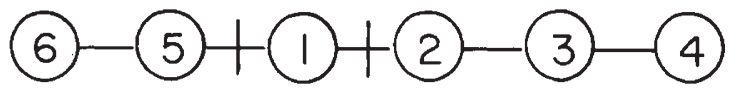

Figure 3 A parsimony network of composite genotypes. Numbers correspond to composite genotypes in Table 2. Hatch marks indicate two or more mutational steps, a +indicates an insertion of 400 base pairs and a-indicates a deletion of 200 base pairs.

where $n_{x y}$ is the number of fragments shared between genotypes, and $n_{x}$ and $n_{y}$ are the total numbers of fragments in genotypes $x$ and $y$ (Nei and $\mathrm{Li}, 1979$ ). This value was used to estimate nucleotide sequence divergence, $p$, by equation $(6 b)$ in Upholt (1977), and the standard error was estimated by equation (7). Nucleotide sequence divergence was estimated for $5 \mathrm{bp}$ - and $6 \mathrm{bp}$ specific restriction enzymes separately and averaged by weighting each $p$ value with the number of nucleotide sites detected by each group of restriction enzymes.

For $M$. capensis, we surveyed 215.6 nucleotide sites on average in each individual (about 1.28 per cent of the mtDNA genome). Estimates of polymorphism were 0.0213 and 0.0222 (S.E. $=0.007$ ) using Engels' (1981) and Hudson's (1982) estimators. For $M$. paradoxus, we surveyed $212 \cdot 3$ base pair sites on average per individuals $(1 \cdot 26$ per cent of the mtDNA genome) and computed estimates of polymorphism of 0.0055 and 0.0089 $($ S.E. $=0.004)$, respectively. A comparison of these levels of polymorphism between species using a $t$-test of arcsin transformed values was highly significant $\left(t^{12}=5 \cdot 04, P<0 \cdot 01\right)$. The amount of sequence divergence, $p$, between genotypes of $M$. capensis ranged from 0.0 to 0.0135 and averaged 0.0057 . For $M$. paradoxus, values of $p$ varied from
0.0010 to 0.0102 and averaged 0.0055 . The average $p$ between composite genotypes of the two species was $0 \cdot 116($ S.E. $=0.036)$.

We estimated the Guanine + Cytosine $(\mathrm{G}+\mathrm{C})$ content of hake mtDNA by centrifuging isolated mtDNA in an isopycnic gradient of $\mathrm{CsCl}$ $\left(1.710 \mathrm{~g} / \mathrm{cm}^{3}\right.$ average density) for 24 hours at $36,000 \times g$ in a Beckman Model E analytical centrifuge. Plasmids from Clostridium acetobutylicum with a $\mathrm{G}+\mathrm{C}$ content of 28 per cent and those from Streptomycetes cattleya with a $\mathrm{G}+\mathrm{C}$ content of 73 per cent were used to calibrate the density gradient. The $\mathrm{G}+\mathrm{C}$ content of $M$. capensis mtDNA was estimated to be 47.0 per cent $( \pm 2$ per cent) and that of $M$. paradoxus to be $45 \cdot 5$ per cent $( \pm 2$ per cent).

\section{DISCUSSION}

\section{$G+C$ content}

Previous studies of the $\mathrm{G}+\mathrm{C}$ content in mtDNA using sedimentation analysis show that birds tend to have the greatest $\mathrm{G}+\mathrm{C}$ content ( $46-50$ per cent), followed by mammals (37-44 per cent) and lower vertebrates (38-41 per cent) (Brown, 1983). The freshwater trout, Salmo gairdneri, had a content of 41 per cent (Brown, 1983). Our estimates of the $\mathrm{G}+\mathrm{C}$ content in hake $(M$. capensis 47 per cent \pm 2 per cent; $M$. paradoxus $45 \cdot 5$ per cent \pm 2 per cent) are somewhat unusual in that they are more similar to higher than to lower vertebrates. Brown (1983) postulated that the $\mathrm{G}+\mathrm{C}$ content may influence the degree to which secondary structures form in polynucleotides and this may influence the efficiency of RNA processing and protein synthesis. In organisms with large energy demands where a high degree of mitochondrial efficiency is required, there may be a selective pressure for a strong $\mathrm{G}+\mathrm{C}$ bias. It is not clear, however, whether this mechanism can explain the difference between trout and hake. Perhaps, a high saline marine environment imposes greater metabolic demands on hakes than does a low saline freshwater environment on trout.

\section{Size polymorphism}

Although nucleotide base pair substitutions are generally responsible for intraspecific differences among mtDNA genotypes, additions or deletions have also been reported. Our results for $X b a$ I and $X$ ho I suggest that an addition of about 400 base pairs and a deletion of about 200 base pairs have occurred along pathways leading from the most 
common genotype in $M$. capensis. We were not able to detect this size variation with other enzymes except possibly with Ava I. The additions may have occurred on large fragments and the sensitivity of our analysis was not great enough to detect them.

Intraspecific deletions and additions have been observed for fruitflies (Drosophila; Fauron and Wolsten-Holme, 1976), tree frogs (Hyla; Bermingham et al., 1986), goats (Upholt and Dawid, 1977) and humans (Aquadro and Greenberg, 1983; Cann and Wilson, 1983). Size polymorphisms within individuals (heteroplasmy) have also been reported for some species of lower vertebrates (Densmore et al., 1985; Bermingham et al., 1986) and a freshwater fish (Bermingham et al., 1986), but we found no evidence of this in the hakes examined here. Most deletions or additions are only a few base pairs in length (Aquadro and Greenberg, 1983; Cann and Wilson, 1983), but others have been several hundred base pairs long (Bermingham et al., 1986). Such large additions and deletions appear to be confined to non-coding regions such as the D-loop (Upholt and Dawid, 1977; Ferris et $a l ., 1981)$ and do not appear to affect the fitnesses of the individuals carrying them. Bermingham et al. (1986) noted that size polymorphisms tended to be more prevalent in lower vertebrates such as fish and reptiles than in mammals.

\section{Nucleotide site variation}

The levels of nucleotide site polymorphism differed between the two hakes, and this difference is reflected in our data in several ways. First, the measures of polymorphisms were significantly different between species at a probability level of $P<0.01$. Second, a total of at least 22 mutations producing 14 composite genotypes were identified in $M$. capensis, but only 12 mutations producing 6 composite genotypes appeared in $M$. paradoxus. The difference is also reflected in the greater complexity in the parsimony network of composite genotypes in $M$. capensis. It is unlikely that the different levels of nucleotide site polymorphism are due to sample errors because we examined a similar number of fish for each species. We cannot rule out the possibility that the difference may be due to a difference in the mutation rates of the two species, but, for lack of evidence, assume that it is the same in both species. It also seems unlikely that these differences are due to differential selection in the two species.

The most likely explanation for the difference in polymorphism between the species is that the two species have experienced different population events. The first possibility is that the two species have different population sizes or different levels of gene flow between populations which produce different levels of within-species polymorphism. We discount this explanation, however, because both species have very large subpopulations which show very little genetic fragmentation between locations (Grant et al., 1988a). Another possibility is that $M$. paradoxus experienced an ancient bottleneck in population size but not $M$. capensis. Although there were no differences in the levels of nuclear variability as measured by protein electrophoresis (Grant et al., 1988b), Wilson et al. (1985) point out that bottleneck effects may still be apparent with mtDNA variation. This is because a single breeding pair possesses four nuclear genomes, but only a single transmissible mtDNA genome. The level of mtDNA diversity is therefore more sensitive to population events than is nuclear diversity.

\section{Geographic variations}

The geographic patterns of mtDNA differentiation show that there is no genetic subdivision of hake stocks in South African waters. Grant et al. (1988a) also found no evidence of genetically discrete stocks within South African waters using allozyme population markers. They did find, however, that for $M$. capensis Namibian stocks to the north were genetically different from South African stocks, at least to a small degree. No allele frequency differences were detected for $M$. paradoxus over the same area. The samples used in the present study were collected only from South African waters because it was not possible to get fresh tissues from Namibian waters. It was, therefore, not possible to determine whether mtDNA markers would also reveal the same regional genetic stocks for $M$ capensis.

In the few species of marine fishes that have been examined, the amount of sequence divergence between intraspecific genotypes generally averages about 1 per cent (table 3 ). But values as large as 4.4 per cent have been observed for some marine fishes (e.g., Atlantic herring, Clupea harengus; Kornfield and Bogdanowicz, in press), and as high as 8.7 per cent between populations (possibly subspecies) for freshwater fishes (Bermingham and Avise, 1986). There appears to be little or no geographic ordering of mtDNA genotypes in marine fishes, most likely because of the general lack of barriers to migration in the sea. Although freshwater fishes and rodents also show 
Table 3 mtDNA sequence divergence between intraspecific genotypes of selected species estimated by the proportion of shared restriction fragments

\begin{tabular}{|c|c|c|c|}
\hline Species & $\begin{array}{l}\text { Mean (range) } \\
\text { sequence } \\
\text { divergence }(\%)\end{array}$ & $\begin{array}{l}\text { Number of } \\
\text { enzymes }\end{array}$ & Reference \\
\hline \multicolumn{4}{|l|}{ Marine fish } \\
\hline Merluccius capensis & $0.6(0.0-1.4)$ & 11 & This study \\
\hline M. paradoxus & $0.5(0 \cdot 1-1 \cdot 0)$ & 11 & This study \\
\hline Katswonus pelamis & $1 \cdot 0$ & 9 & Graves et al., 1984 \\
\hline Anguilla rostrata & $0.1(0.0-0.6)$ & 14 & Avise et al., 1986 \\
\hline Clupea harengus & $1 \cdot 7(0 \cdot 2-4 \cdot 4)$ & 7 & $\begin{array}{l}\text { Kornfield and Bogdanowizc, in the } \\
\text { press }\end{array}$ \\
\hline \multicolumn{4}{|l|}{ Marine invertebrates } \\
\hline Limulus polyphemus & $2 \cdot 0$ & 12 & Saunders et al., 1986 \\
\hline Mytilus edulis & 0.7 & 7 & Skibinski, 1985 \\
\hline M. galloprovincialis & $1 \cdot 3$ & 7 & Skibinski, 1985 \\
\hline \multicolumn{4}{|l|}{ Freshwater fish } \\
\hline Lepomis cyanullus & $1 \cdot 4$ & 13 & Avise and Saunders, 1984 \\
\hline L. machrochirus & 0.7 & 13 & Avise and Saunders, 1984 \\
\hline L. puntatus & $6 \cdot 2$ & 17 & Bermingham and Avise, 1986 \\
\hline L. microlophus & $8 \cdot 7$ & 17 & Bermingham and Avise, 1986 \\
\hline \multicolumn{4}{|l|}{ Birds } \\
\hline Parus atricapillus & $0 \cdot 4$ & 14 & Mack et al., 1986 \\
\hline \multicolumn{4}{|l|}{ Rodents } \\
\hline \multicolumn{4}{|l|}{ Geomys pinetis } \\
\hline within regions & 0.3 & 6 & Avise et al., 1979 \\
\hline between regions & $3 \cdot 4$ & 6 & Avise et al., 1979 \\
\hline Peromysus polionotus & $1 \cdot 1^{*}$ & 8 & Avise et al., 1983 \\
\hline P. maniculatus & $0.4^{*}$ & 8 & Lansman et al., 1983 \\
\hline Rattus norvegicus & $0.7(0.4-1 \cdot 8)^{*}$ & 7 & Brown and Simpson, 1981 \\
\hline R. rattus & $4 \cdot 2(0 \cdot 4-9 \cdot 6)^{*}$ & 7 & Brown and Simpson, 1981 \\
\hline \multicolumn{4}{|l|}{ Primates } \\
\hline Homo sapiens & $2 \cdot 3^{*}$ & 12 & Cann et al., 1987 \\
\hline
\end{tabular}

* Estimated by restriction site maps.

a similar degree of differentiation among mtDNA genotypes (table 3 ), these genotypes usually correspond to geographic populations because physical barriers to migration between lakes or between areas prevent the homogenising effects of gene flow (Bermingham and Avise, 1986).

\section{Interspecific divergence}

Although mtDNA sequence divergence has been measured for several pairs of species over a wide taxonomic range, these values may not be comparable because of differences in the numbers of restriction enzymes used in the various studies and because of possible differences in the evolutionary rates in different groups. None the less, closely related sibling species (e.g., Drosophila; Solignac et al., 1986) have $p$ values on the order of 5 per cent, whereas more distantly related species have $p$ values of 10 per cent or greater (e.g., Lepomis; Avise and Saunders, 1984). Our estimate of
mtDNA sequence divergence between the two species of hake ( 11.6 per cent $)$ is typical of well differentiated congeneric species (table 4).

Measures of sequence divergence have been used to estimate the amount of time since species have diverged from one another. Brown et al. (1979) found that for primates the rate of sequence evolution was linear up to a $p$ value of 0.15 and derived a calibration of 2 per cent divergence per one million years over this range. Beyond this range the rate of sequence evolution slowed considerably. No time calibrations have been made for lower vertebrates or for fishes in particular, but time estimates using this calibration appear to be at least approximately correct for freshwater fishes (Bermingham and Avise, 1986). The estimate of sequence divergence between the southern African hakes was within the linear range of the calibration curve and yielded an estimate of $5 \cdot 8($ S.E. $=1 \cdot 8$ ) million years. This estimate is considerably less than the 10 million years estimated with nuclear 
Table 4 Mean (range) mtDNA sequence divergence between congeneric species estimated by the proportion of shared restriction fragments

\begin{tabular}{|c|c|c|c|c|}
\hline Genus & $\begin{array}{l}\text { Number of } \\
\text { species }\end{array}$ & $\begin{array}{l}\text { Mean sequence } \\
\text { divergence }(\%)\end{array}$ & $\begin{array}{l}\text { Number of } \\
\text { enzymes }\end{array}$ & Reference \\
\hline \multicolumn{5}{|l|}{ Insects } \\
\hline Drosophila & 10 & $5 \cdot 7(1 \cdot 5-9 \cdot 7)^{*}$ & 9 & Solignac et al., 1986 \\
\hline \multicolumn{5}{|l|}{ Amphibians } \\
\hline Rana & 2 & $8 \cdot 1$ & 19 & Spolsky and Uzzell, 1984 \\
\hline \multicolumn{5}{|l|}{ Marine fish } \\
\hline Merluccius & 2 & $11 \cdot 6$ & 11 & This study \\
\hline \multicolumn{5}{|c|}{ Freshwater fish } \\
\hline Lepomis & 9 & $20 \cdot 1(7 \cdot 0-25)$ & 13 & Avise and Saunders, 1984 \\
\hline Salmo & 4 & $9 \cdot 3(4 \cdot 1-13 \cdot 7)$ & 13 & Gyllensten and Wilson, 1987 \\
\hline \multicolumn{5}{|l|}{ Birds } \\
\hline Parus & 3 & $7 \cdot 0(4 \cdot 0-9 \cdot 0)$ & 14 & Mack et al., 1986 \\
\hline \multicolumn{5}{|l|}{ Rodents } \\
\hline Mus & 2 & $5 \cdot 0$ & 3 & Ferris et al., 1983 \\
\hline Permyscus & 2 & $14 \cdot 1$ & 6 & Lansman et al., 1979 \\
\hline Rattus & 2 & $16 \cdot 2(13 \cdot 5-18 \cdot 4)^{*}$ & 7 & Brown and Simpson, 1981 \\
\hline \multicolumn{5}{|l|}{ Primates } \\
\hline Pan & 2 & $3 \cdot 7^{*}$ & 15 & Ferris et al., 1981 \\
\hline
\end{tabular}

* Estimated from restriction site maps.

genes (Grant et al., 1988b). The difference between the two estimates may indicate that calibration of $p$ based on primate data is inappropriate for lower vertebrates, or may be due to the large errors inherent in each method.

Acknowledgements We thank E. Moore and C. Ovadio (1rving and Johnson Fish Company, Cape Town) and Rob Leslie (Sea Fisheries Research Institute) for arranging the collection of fresh tissue samples for the mtDNA analysis, and E. Bermingham for comments on the manuscript. This study was supported by the Sea Fisheries Research Institute, Cape Town.

\section{REFERENCES}

AQUAdRo, C. F. AND GREENBERG, B. D. 1983. Human mitochondrial DNA variation and evolution: analysis of nucleotide sequences from seven individuals. Genetics, 103 , 287-312.

AVISE, J. C. AND SAUNDERS, N. C. 1984. Hybridization and introgression among species of sunfish (Lepomis): analysis by mitochondrial DNA and allozyme markers. Genetics, $108,237-255$.

AVISE, J. C., LANSMAN, R. A. AND SHADE, R. O. 1979. The use of restriction endonucleases to measure mitochondrial DNA sequence relatedness in natural populations. I. Population structure and evolution in the genus Permyscus. Genetics, 92, 279-295.

AVISE, J. C., SHAPIRA, J. F., DANIEL, S. W., AQUADRO, C. F. AND LANSMAN, R. A. 1983. Mitochondrial DNA differentiation during the speciation process in Peromyscus. Mol. Biol. Evol. 1, 38-56.
AViSE, J. C., HELFMAN, G. S., SAUNDERS, N. C. AND HALES, L. S. 1986. Mitochondrial DNA differentiation in North Atlantic eels: population genetic consequences of an unusual life history pattern. Proc. Natl. Acad. Sci. USA, $83,4350-4354$.

BERMINGHAM, E. AND AVISE, J. C. 1986. Molecular zoogeography of freshwater fishes in the southeastern United States. Genetics, 113, 939-965.

BERMingham, E., LAMB T. AND AVISE, J. C. 1986. Size polymorphism and heteroplasmy in the mitochondrial DNA of lower vertebrates. J. Heredity, 77, 249-252.

BROWN, G. G. AND SIMPSON, M. V. 1981. Intra- and interspecific variation of the mitochondrial genome in Rattus norvegicus and Rattus rattus: restriction enzyme analysis of variant mitochondrial DNA molecules and their evolutionary relationships. Genetics, 97, 125-143.

BROWN, W. M. 1983. Evolution of animal mitochondrial DNA. Chapter 4. In Nei, M. and Koehn, R. K. (eds.) Evolution of Genes and Proteins. Sinauer Assoc., Sunderland, Mass, USA, pp. 62-88.

BROWN, W. M., GEORGE, M., Jr. AND WILSON, A. C. 1979. Rapid evolution of animal mitochondrial DNA. Proc. Natl. Acad. Sci. USA, 76, 1967-1971.

CANN, R. L., AND WILSON, A. C. 1983. Length mutations in human mitochondrial DNA. Genetics, 104, 699-711.

CANN, R, L., STONEKING, M. AND WILSON, A. C. 1987. Mitochondrial DNA and human evolution. Nature 325, 31-36.

CHAPMAN, R. W. AND POWERS, D. A. 1984. A method for the rapid isolation of mitochondrial DNA from fishes. Tech. Rep. Maryland Sea Grant Prog. No. UM-SG-TS-84-05, $11 \mathrm{p}$.

DENSMORE, L. D., WRIGHT, J. W. AND BROWN, W. M. 1985 Length variation and heteroplasmy are frequent in mitochondrial DNA from parthenogenetic and bisexual lizards (genus Chemidorphorus). Genetics, 110, 689-707. 
ENGELS, W. R. 1981. Estimating genetic divergence and genetic variability with restriction endonucleases. Proc. Natl. Acad. Sci. USA, 78, 6329-6333.

FAURON, C. M.-R. AND WOLSTEN-HOLME, D. R. 1976. Structural heterogeneity of mitochondrial DNA molecules within the genus Drosophila. Proc. Natl. Acad. Sci. USA, $73,3623-3627$.

FERRIS, S. D., BROWN, W. M., DAVIDSON, W. S. AND WILSON, A. C. 1981. Extensive polymorphism in the mitochondrial DNA of apes. Proc. Natl. Acad. Sci. USA. 78, 6319-6323.

FERRIS, S. D., SAGE, R. D., PRAGER, E. M., RITTE, V. AND WILSON, A. C. 1983. Mitochondrial DNA evolution in mice. Genetics, 105, 681-721.

GILES, R. E., BLANC, H., CANN, H. M. AND WALlACE, D. C. 1980. Maternal inheritance of human mitochondrial DNA. Proc. Acad. Sci. USA, 77, 6715-6719.

GRANT, W. S., LESLIE, R. W. AND BECKER, I. I. 1988 a. Genetic stock structure of the southern African hakes. Merluccius capensis and M. paradoxus. Mar. Ecol. Prog. Ser. (In press).

GRANT, W. S., BECKER, I. I. AND LESLIE, R. W. 1988 b. Evolutionary divergence between sympatric species of southern African hakes, Merluccius capensis and $M$. paradoxus. I. Electrophoretic analysis of proteins. Heredity, 61, 13-20.

GRAVES, J. E., FERRIS, S. D. AND DIZON, A. E. 1984. Close genetic similarity of Atlantic and Pacific skipjack tuna (Katsuwonus pelamis) demonstrated with restriction endonuclease analysis of mitochondrial DNA. Mar. Biol., $79,315-319$.

GYLLENSTEN, U. AND WILSON, A. C. 1987. Mitochondrial DNA of salmonids: inter- and intraspecific variability detected with restriction enzymes. In Ryman, N., and Utter, F. M. (eds.) Population Genetics and Fishery Management, Washington Sea Grant Prog., Univ. Washington Press, Seattle, Washington, pp. 301-317.

HUDSON, R. R. 1982. Estimating genetic variability with restriction endonucleases. Genetics, 100, 711-719.

KORNFIELD, I. AND BOGDANOWICZ, S. M. 1987. Differentiation of mitochondrial DNA in Atlantic herring. Fish. Bull, $U S A$, (in press).

LANSMAN, R. A., SHADE, R. O., SHAPIRA, J. F. AND AVISE, J. C. 1981. The use of restriction endonucleases to measure mtDNA sequence relatedness in natural populations. III. Techniques and potential applications. J. Mol. Evol. 17, 214-226
LANSMAN, R. A., AVISE, J. C., AQUADRO, C. F., SHAPIRA, J. F. AND DANIEL, S. W. 1983. Extensive genetic variation in mitochondrial DNAs among geographic populations of the deer mouse. Peromyscus maniculatus. Evolution, 37, $1-16$.

LAMB, T. AND AVISE, J. C. 1986. Directional introgression of mitochondrial DNA in a hybrid population of tree frogs: the influence of mating behavior. Proc. Natl. Acad. Sci. USA, 83, 2526-2530.

MACK, A. L., GILL, F. B., COLBURN, R. AND SPOLSKY, C. 1986. Mitochondrial DNA: a source of genetic markers for studies of similar passerine bird species. Auk, 103, 676-681.

MANIATIS, T., FRITSCH, E. F. AND SAMBROOK, J. 1982 Molecular Cloning. Cold Spring Harbor Lab., New York.

NEI, M., AND LI, w. H. 1979. Mathematical model for studying genetic variation in terms of restriction endonucleases. Proc. Natl. Acad. Sci. USA, 76, 5269-5273.

SAUNDERS, N.C., KESSLER, L. G. AND AVISE, J.C. 1986. Genetic variation and geographic differentiation in mitochondrial DNA of the horseshoe crab, Limulus polyphemus. Genetics, $112,613-627$.

SKIBINSKI, D. O. F. 1985. Mitochondrial DNA variation in Mytilus edulis L. and the Padstow mussel. J. Mar. Biol. Ecol., 92, 251-258.

SOLIGNAC, M., MONNEROT, M. AND J.-C. MOUNOLOU. 1986. Mitochondrial DNA evolution in the melanogaster species subgroup of Drosophila. J. Mol. Evol., 23, 31-40.

SPOLSKY, C. AND UZZELL, T. 1984. Natural interspecies transfer of mitochondrial DNA in amphibians. Proc. Natl. Acad Sci. USA, 81, 5802-5805.

UPHOLT, W. B. 1977. Estimation of DNA sequence divergence from comparison of restriction endonuclease digests. $\mathrm{Nucl}$. Acid. Res., 4, 1257-1267.

UPHOLT, W. B. AND DAWID, I. B. 1977. Mapping of mitochondrial DNA of individual sheep and goats: rapid evolution in the D-loop region. Cell, 11, 571-583.

WILSON, A. C., CANN, R. L., CARR, S. M., GEORGE, M., GYLLENSTEN, U. B., HELM-BYCHOWSKI, K. M., HIGUCHI, R. G., PALUMBI, S. R., PRAGER, E. M., SAGE, R. D. AND STONEKING, M. 1985. Mitochondrial DNA and two perspectives on evolutionary genetics. Biol. J. Linn. Soc., 26, 375-400. 